\title{
A Letter from the TMS President: Membership Opens Doors to Professional Growth
}

\author{
Garry Warren
}

Dear TMS Colleague,

As president of The Minerals, Metals \& Materials Society, I'd like to invite you to make the same choice I have since I entered this profession: Take advantage of the many opportunities TMS provides to grow professionally and make a difference in the world by renewing your membership.

During my tenure with this organization, TMS has continually found new ways to meet the needs of materials scientists and engineers who are at the leading edge of an ever-evolving profession. With its conferences, publications, and networking opportunities, through economic booms and busts, TMS has enabled me to advance my career.

Through TMS, I have met and been mentored by leaders of our profession. By serving on various committees and in other volunteer positions, I was able to sharpen my leadership skills as I helped shape the Society's priorities. At so many TMS conferences, I learned of new developments in materials science and engineering that broadened my knowledge base and frequently led to new ideas for my own research.

As you can see, the ways I have personally and professionally grown through membership in TMS are many. However, I would be remiss if I did not mention the more direct tangible value for my membership dues: all members receive a suite of benefits that well exceed the cost of membership dues.
Here is a sampling of some the key benefits of TMS membership you will most assuredly find invaluable:

- Access to both the print and electronic versions of JOM, our member journal featuring society news, materials-themed feature articles, and academic, industrial, and government sponsored work from around the world. (Significantly, $J O M$ will be expanding to more pages with the January issue.)

\section{With its conferences,} publications, and networking opportunities, through economic booms and busts, TMS has enabled me to advance my career.

- E-subscriptions to The Journal of Electronic Materials, Metallurgical and Materials Transactions A and $B$, and 20 additional materials-themed journals published by Springer

- Discounts on purchases of John Wiley \& Sons publications

- Substantial discounts on many TMS meeting registrations

- Access to professional development and mentoring resources de- veloped by materials professionals for materials professionals

- The opportunity to enrich our society and build your curriculum vitae by volunteering your skills as a member of a technical committee

- Networking opportunities with colleagues from around the world through TMS-sponsored meetings, short courses, and social networking sites such as LinkedIn and Facebook

- Full access to the TMS Membership Directory, where you can connect with colleagues of similar interests

As you can see, your TMS membership offers a great return on your investment.

Furthermore, there is always so much to experience as a member of TMS because we are always adding or improving services and career opportunities.

To prevent interruption in your TMS benefits, please respond immediately to the dues renewal messages you will soon receive. To all of our members, rest assured that we truly value your continued membership. To prospective members, I invite you to join this vibrant, dedicated group of professionals.

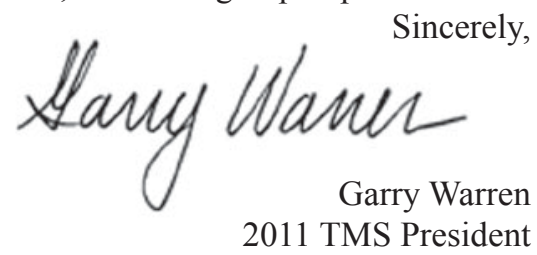

